\title{
Interventions and Management of Postpartum Hemorrhage: A Literature Review
}

\author{
Dida Rosida, Yanti Hermayanti, Sukmawati \\ Faculty of Nursing, Universitas Padjadjaran \\ Email:didhasp@gmail.com
}

\begin{abstract}
Bleeding is the main cause of maternal mortality in the world, the mortality rate due to bleeding about $30.3 \%$ in Indonesia in 2013. Dealing bleeding during and after labor is very important for health professionals including nurses. Research on the management of postpartum hemorrhage is still limited. The purpose of this literature review was to determine the management of postpartum hemorrhage from various countries. The method, this literature review involved articles that published in 2008-2018. The articles searched from several databases, including ProQuest, 32 articles, PubMed 22 articles, and Google 21 scholar articles. Keywords for article search included postpartum hemorrhage, nurse, prevention, treatment, management, and intervention. 75 articles were assessed for the quality using the JBI instrument (Joanna Briggs Institute), and finally, 10 articles were found and met the inclusion criteria. The results show that there are two types of actions to deal with postpartum hemorrhage including direct treatment and indirect treatment. The direct treatment includes bimanual compression, maneuvering techniques, balloon tampons, and tools resembling a butterfly shape for bimanual compression. Indirect actions include training of health workers, initiation of early breastfeeding and ice packs. Conclusion, effective management both directly and indirectly is able to overcome postpartum hemorrhage. Health workers are expected to master effective ways to deal with postpartum hemorrhage.
\end{abstract}

Keywords: Intervention, management, nursing, postpartum hemorrhage, prevention . 
Dida Rosida: Interventions and Management of Post Partum Hemorrhage: A Literature Review

\section{Introduction}

The maternal mortality rate is one of the most important indicators in determining the mothers' health status in a country, at this time the incidence of maternal mortality is still high, especially in developing countries. WHO data reports that Indonesia is included in the top 10 countries contributing to maternal mortality in the world (WHO, 2016). The maternal mortality rate in Indonesia ranged from 305 per 100,000 live births in 2015, while in West Java the maternal mortality rate in 2015 ranged from 102 per 100,000 live births (West Java Provincial Health Office, 2016), and in Garut Regency in 2016 maternal deaths ranged from 74 cases to total births of 56,177 with a ratio of 131.73 (District Health Office of Garut Regency, 2017). While the national health target in the SDGs in 2030 is to establish a reduction in maternal mortality below 70 per 100,000 live births, based on these conditions, indicating that in Indonesia the maternal mortality rate is still high and still far away from the targets set by the SDGs (Ministry of Health, 2016).

The causes of maternal deaths are mostly due to hemorrhage, including 24 hours after giving birth to the baby (postpartum period). According to the WHO in 2018, the main cause of maternal death is caused by postpartum hemorrhage, in Indonesia, the highest maternal mortality rate in 2013 was due to bleeding after giving birth which was around 30.3\% (RI Ministry of Health, 2014). In West Java, the highest cause of AKI due to bleeding during and after childbirth ranged from 204 cases (West Java Health Office, 2018). National statistical data in the United States states that $8 \%$ of maternal deaths are due to postpartum hemorrhage (Nugroho, 2012). Postpartum hemorrhage is bleeding that occurs before and after the birth of the baby and, during and after the birth of the placenta, the mother experiences blood loss $>500 \mathrm{cc}$ in vaginal delivery and blood loss $>1000 \mathrm{cc}$ in the labor section Caesarea (SC) (Oxorn Harry \& William R. Forte, 2010). Postpartum hemorrhage based on the occurrence timing, its consists of 2 parts namely primary postpartum hemorrhage (Early Postpartum Hemorrhage) which occurs in the first 24 hours after delivery usually due to uterine atony, birth canal injury, placental retention and remaining part of the placenta. The second, secondary or advanced postpartum hemorrhage (Late Postpartum Hemorrhage) occurs after 24 hours of labor usually due to infection, the remaining part of the placenta and uterine involution is not good. The most common cause of maternal death is primary postpartum hemorrhage (Manuaba, 2008).

Several studies suggest that uterine atony is a major cause of postpartum hemorrhage that causes maternal death. The research conducted by Yuliawati and Anggraini in 2015 at Muhammadiyah Hospital in Metro City, the incidence of uterine atony would increase 8.9 times the incidence of postpartum hemorrhage compared to women without uterine atony (Yuliawati \& Anggraini, 2015). Uterine atonia is the inability of the uterus to contract because there is a disruption of function in the myometrium, an effort to control the occurrence of bleeding from the placenta by improving contraction and retraction of myometrial fibers, contractions and retractions causing folds of blood vessels so that blood flow to the placenta stops (Oxorn Harry \& William R. Forte, 2010). Effective treatment of health workers including nurses is needed to deal with postpartum hemorrhage because nurses are one of the professional health officers who have several roles including advocates, collaborators, educators, provision of care services and as researchers who must have a role as a renewal in the provision of care optimal and comprehensive.

Based on these conditions, it is illustrated that bleeding cases are still the main cause of maternal mortality in developing countries including in Indonesia, in Indonesia various treatments and management are carried out to stop bleeding, prevent shock, this has been explained in theory but Indonesian literature regarding handling of postpartum hemorrhage, only found 5 articles. Various types of treatments that have been carried out in Indonesia, which are recommended by WHO, are by uterine massage fundus technique, bimanual compression, and further treatment with medical treatment such as drugs to stop bleeding, and most articles in Indonesia also only describe the incidence of bleeding, looking for the relationship 
Dida Rosida: Interventions and Management of Post Partum Hemorrhage: A Literature Review

between risk factors and the occurrence of postpartum hemorrhage so that research on the types and methods of interventions and management carried out to overcome postpartum hemorrhage is still limited. So that it takes a variety of information for health workers in dealing with postpartum hemorrhage.

Based on the phenomenon that occurs at this time, the researchers made a research question about how to handle and manage mothers who experience postpartum hemorrhage performed in various countries, both developed and developing countries, using literature studies. The purpose of this study was to identify and analyze the description of interventions and management of postpartum hemorrhage in various countries.

\section{Research Method}

Researchers conducted national and international articles searching through electronic media with the Google Scholar, Pubmed, Proquest databases using keywords: postpartum hemorrhage, intervention, nurse, prevention, treatment, management, and techniques. Articles selected base on inclusion criteria including full-text articles, samples were mothers experiencing postpartum hemorrhage, year of publication of articles at the latest 10 years (2008 - 2018), articles on interventions and management of postpartum hemorrhage, and nursing intervention articles. The article chosen was in the form of quantitative and qualitative research with various types of research methods used in each article.

\section{Research Results}

Articles obtained from the entire database, 77 articles were then screened from the title, abstract, research method, type of intervention to obtain 10 articles from various countries such as the United Kingdom, Japan and several articles from developing countries such as Indonesia, Rural Hundreds, Pakistan, Iran , Ghana and Egypt. Articles carried out an analysis and evaluation of articles (critical appraisal) using instruments from JBI (Joanna
Briggs Institute) to provide an assessment for each article.

\section{Discussion}

The number of articles obtained in accordance with the inclusion criteria are 10 articles from developed and developing countries. Articles informed the research methods, samples, main problems faced in each country, causes of bleeding, nursing interventions for handling postpartum hemorrhage. These articles carried out research in hospitals, universities, health services / PHC/ clinic. Each article has different from research methods and differs in the main problems faced by each country

Bleeding during the postpartum period is the cause of serious and most common blood loss during pregnancy and childbirth. Postpartum hemorrhage is a blood loss more than $500 \mathrm{ml}$ after vaginal birth and 1000 $\mathrm{ml}$ for cesarean delivery, physiologically the mother who has given birth will bleed about $500 \mathrm{ml}$ in the absence of homeostatic disorders, because with a $10 \%$ change in the hematocrit after labor it can be said as postpartum hemorrhage (Lowdermilk, Perry \& Cashion, 2013). This postpartum hemorrhage is a major problem causing high maternal mortality rates in developing countries and some developed countries. In Japan, postpartum hemorrhage accounts for $20 \%$ of total maternal births. The article does not explain how many cases of maternal mortality in each country.

In developing countries, there are other factors that would increase the incidence of maternal mortality such as the difficulty to access health services, inadequate resources, mothers who are anemic, and health workers still do not understand the handling of bleeding and third-time management. However, it is different from developed countries with economic condition better than developing countries.

Various causes of bleeding in studies from developed and developing countries include uterine atony as described in the maternity nursing book. The author of Lowdermilk, Perry \& Cashion (2013) states that uterine atony is the main cause of postpartum hemorrhage because of the inability of the 
Dida Rosida: Interventions and Management of Post Partum Hemorrhage: A Literature Review

uterus to contract properly after labor, there is a disturbance in myometrial fibers because in myometrial fibers there is smooth muscle and traversed by large blood vessels mother so that if the uterus does not contract or the uterus undergoes relaxation after the birth of the placenta then bleeding will occur, clotting of the blood vessels becomes disturbed and continues until the uterus re-contracts. Other direct causes include in the State of Egypt, namely the third stage of management which is not good, whereas in the theory it explains that management of the third stage is a very important process for preventing or overcoming postpartum bleeding. The intervention aims to accelerate the birth of the placenta by increasing uterine contractions so as to reduce the incidence of bleeding due to uterine atony. Management of stage management includes three main components, namely uterotonic administration, controlled cord pull, uterine massage after the placenta is born (Siswosudarmo, R., 2016 ).

Causes of Bleeding in several developing countries such as Egypt, Ghana, Rural Hundreds are experiencing difficulties in access to health services in Rural Hundreds, and nurses who are still less capable in management the third period of give birth, because of inadequate resources. In the State of Egypt there is a cause because mothers who have a history of anemia which is a deficiency of $\mathrm{Hb}$ in the blood which affects the oxygen level in the blood, where oxygen is carried throughout the body and brain, so if this anemia is not handled it will affect the mother who has given birth. In mothers who have given birth who have a history of anemia, they will experience uterine atony, this is because oxygen flowing into the uterus decreases to more severe bleeding. Whereas in Indonesia there are other causes, namely a history of more than 4 parties, preeclampsia/ eclampsia, the presence of comorbidities and other infections but not explained the type of comorbidities and their infections.

Various types of interventions are carried out in various countries with different results of effectiveness, there are several countries that carry out the same treatment, there are 2 articles according to Low Lisa K et al., 2008 in Rural Hundreds and Ibrahim H, A, F and Menim S, O, A in Egypt in handling the same as training to nurses, according to Low Lisa $\mathrm{K}$ et al. Prevented by active management 3 times by training nurses to be able to do it because in Rural Hundarus nurses were still lacking in the ability to implement active management of the third period, train nurses to be able to control blood loss, such as uterine massage, bimanual compression, correct hypovolemia after oxytocin administration and placental examination. And according to Ibrahim and Menim, a way to improve the performance of maternity nurses regarding prevention and control of postpartum bleeding to evaluate the effectiveness of educational interventions on improving the performance of maternity nurses in dealing with prevention and control of postpartum hemorrhage so that the results are effective in improving nurse performance. Research by Hanan Fahmi Azzam \& Nadia Bassiouni E.S in 2014 intervening with a quasi-experimental approach saw the effect of the nursing protocol for handling bleeding. Conduct an experiment in accordance with the protocol, namely for treatment in the form of handling shock, Secondary steps such as continuous uterine massage is done to stimulate the uterus. These results are effective to overcome postpartum hemorrhage in accordance with predetermined nursing protocols (Azzam, H., F., \& Nadia, B., E., 2014; Ibrahim, H., A., F \& Menim, S., O., A. 2016; Low, Lisa, K. et al 2008).

Indonesia applies bimanual compression to treat postpartum hemorrhage, the same treatment also applies in the State of Ghana. In Ghana, the bimanual compression did on the obstetrical manikin, while in Indonesia the collecting data did in health services. This treatment is effective for dealing with bleeding, while in developed countries, for example, the United Kingdom, according to Cunningham $\mathrm{C}$ designed a tool to do compression by using a butterfly-like device to obstetric beads alone because it still proved the new tool to deal with the handling of postpartum hemorrhage. This tool is a plastic pessary platform designed with a handle to make it easier for users to press the uterus. There is a channel to find out the location of bleeding but this tool still requires clinical evidence, and it is recommended to do further research in the patient directly. A study in Egypt used another technique to solve uterus 
Dida Rosida: Interventions and Management of Post Partum Hemorrhage: A Literature Review

atony. This technique of maneuver can be done to overcome postpartum hemorrhage, balloon tampons can be a treatment option that can be done to treat postpartum hemorrhage (Amr, H., 2014; Andreatta, P., et al 2012; C, Cunningham. 2017; Lestari P., P. 2017).

Early breastfeeding initiation (IMD) is a technique that can affect the occurrence of uterine involution quickly so that it would stimulate the hormone oxytocin which serves to stimulate the breast muscle and retraction of the uterine muscles, it will suppress blood vessels resulting in a lack of blood supply to the uterus, and this process helps to reduce placental implantation sites and reduce bleeding. The release of the oxytocin hormone also makes the mother calm, relax, euphoria, increase the pain threshold so that she can love her baby. The process of IMD include touch, suction, and licking on the nipple will stimulate the release of the hormone oxytocin which is very important to increase uterine contractions and to reduce the risk of bleeding in the mother. IMD also helps the mother to relax and away from stress conditions, the production of oxytocin can increase (Pawestri, N., K., 2017). If the bleeding continues and the uterus is still soft while uterine massage and bimanual compression have been done then balloon tampon would be done to overcome postpartum hemorrhage as in the Zafar Sardar Study., A. et al. (2017). This study was conducted in hospitals in Pakistan. The balloon tampons performed effective results to overcome bleeding after childbirth so that the mother does not end on the operating table. From all articles about intervention and manage postpartum hemorrhage there are treatments that are carried out directly and indirectly so that the treatment carried out directly at the source of the bleeding is effective to overcome postpartum hemorrhage. However, indirect actions such as the initiation of early breastfeeding are effective for dealing with bleeding

\section{Conclusion}

Effective management hemorrhage cases are carried out by directly carrying out bimanual compression, compression with tools, maneuvering techniques, uterine massage, balloon tampons, and there are also indirect effective treatments including initiation of early breastfeeding, training of health workers. Some studies that have been examined by researchers are using uterine massage, bimanual compression and initiation of early breastfeeding. For health workers to be able to master ways that effectively deal with postpartum hemorrhage. For further research, clinical evidence regarding research with observational or quasi-experimental methods is needed and stimulates students to conduct further research.

\section{References}

Amr Hamdy. (2014). A Maneuver For Prevention Of Postpartum Haemorrhage. The Journal Of Obstetrics And Gynecology Of India. Doi 10.1007/s13224-014-0592-6.

Andreatta P, Perosky J, BSME, Johnson, Timothy. (2012). Two-Provider Technique For Bimanual Uterine Compression to Control Postpartum Hemorrhage. Journal of Midwifery \&Women's Health.

Anggraini, Y. 2010. Asuhan Kebidanan Masa Nifas. Yogyakarta: Pustaka Rihana.

Azzam, H., F., \& Nadia, B., E., S. (2014). Effect of nursing care protocol on atonic postpartum hemorrhage outcomes. World Journal of Nursing Sciences 3S: 32-45.

C, Cunningham et al. (2017). PPH Butterfly: a Novel Device To Treat Postpartum Haemorrhage Through Uterine Compression. BMJ innov 2017;3;45-54. Doi: 10.1136/ bmjinnov-2016-000144.

Dinas Kesehatan Provinsi Jawa Barat. 2018. Profil Kesehatan Provinsi Jawa Barat (Angka kematian ibu) tahun 2017.

Dinas Kesehatan Provinsi Jawa Barat. 2017. Profil Kesehatan Provinsi Jawa Barat (Angka Kematian Ibu Tahun 2016).

Dinas Kesehatan Provinsi Jawa Barat. 2015. Profil Kesehatan Provinsi Jawa Barat (Angka 
Dida Rosida: Interventions and Management of Post Partum Hemorrhage: A Literature Review

Kematian Ibu Tahun 2014).

Firouzbakht M, Kiapour A, \& Omidvar S. (2013). Prevention Of Post-Partum Hemorrhage by Rectal Misoprostol: A Randomized Clinical Trial. Journal of Natural Science, Biology and Medicine, 4(1).

Ibrahim H A F \& Menim S O A. 2016. Improving Maternity Nurses Performance Regarding Prevention and Control Of Postpartum Hemorrhage. International Journal of Novel Research in Healthcare and Nursing, 3(3) : (101-115).

Instrument joanna briggs institute, di unduh dari http://joannabriggs.org/research/criticalappraisal-tools.html.

Kementrian kesehatan 2016. Profil Kesehatan (Angka kematian ibu) tahun 2015.

Kementrian kesehatan 2014. Profil Kesehatan (penyebab kematian Ibu) tahun 2013.

Low Lisa K, Bailey J M, Sacks E, Medina L, \& Piñeda H O L. (2008). Postpartum Hemorrhage Prevention: A Case Study in Northern Rural Hundarus. Journal of Midwifery \& Women's Health .

Lowdermilk, Perry \& Cashion. (2013). Keperawatan Maternitas Edisi 8 buku 2. Singapura : Elsevier .

Manuaba. 2008. Ilmu Kebidanan Penyakit Kandungan dan KB. Jakarta : EGC .

Masuzawa Y, Kataoka Y, Nakamaru S, \& Yaju Y. (2017). Cooling The Lower Abdomen To Reduce Postpartum Blood Loss: A Randomized Controlled Trial. PLOS ONE 12(10): e0186365, https://doi.org/10.1371/ journal.pone.0186365.

Nugroho, T. (2012). Obgyn Obstetri dan Ginekologi Untuk Kebidanan dan Keperawatan. Yogyakarta: Nuha Medika.

Oxorn, Harry, et al. 2010. Ilmu Kebidanan Patologi \& Fisiologi Persalinan. Yogyakarta: Yayasan Essentia Medica (Yem).

Pawestri, Nikmatul K. (2017). Pengaruh IMD( inisiasi Menyusui Dini) Dengan Perdarahan Ibu 2 Jam Postpartum di Kota Semarang. Universitas Muhamadiyah Semarang .

Lestari, P., P. (2014). Keberhasilan Penatalaksanaan Perdarahan Postpartum Karena Atonia Uteri KBI dan KBE. Jurnal Keperawatan Aisyiyah (JKA), 1(2).

Siswosudarmo, Risanto. (2016). Penanganan Perdarahan Pascasalin terkini dalam Upaya menurunkan Angka Kematian Ibu. Yogyakarta .

World health Organization (WHO).2016. Trend In Maternal Mortality 1990-2015.

2012.Recommendation For The Prevention And Treatment of Postpartum Hemorrhage. Geneva: WHO Library Cataloguing-inpublication Data.

Zafar S A, Shaukat A, Khalid A, Niaz A, \& Noor S. (2017). Post Partum Hemorrhage; Efficacy Balloon Tamponade In The Management. Professional Med $J$ 2017;24(9);1347-1353.

Zed, Mestika. 2008. Metode Penelitian Kepustakaan. Jakarta: Buku Obor. 